\title{
Transcription of Human Herpesvirus-like Agent (HHV-8) in Kaposi's Sarcoma
}

Yao Qi Huang, Jian Jun Li, Wei-Guo Zhang, Deborah Feiner, and Alvin E. Friedman-Kien

Departments of Dermatology and Microbiology, New York University Medical Center, New York 10016

\begin{abstract}
Recently, DNA sequences of what appear to be a unique human herpesvirus-like agent (HHV-8) have been detected in different types of Kaposi's sarcoma (KS) tumors (Chang, Y., E.C. Cesarman, M.S. Pessin, F. Lee, J.C. Culpepper, D.M. Knowles, and P.S. Moore. 1994. Science (Wash. DC). 266:1865-1869). To further elucidate the possibility that $\mathrm{HHV}-8$ plays a role in the pathogenesis of $\mathrm{KS}$, the expression of HHV-8 RNA was examined in fresh KS tissue specimens which were found to harbor HHV-8 DNA by polymerase chain reaction (PCR). The transcription of $\mathrm{HHV}-8$ RNA was detected by RT-PCR in 26 of 29 specimens $(89.7 \%)$ of the KS tumors including 2 of 3 CKS and 24 of 26 AIDS-KS. No positive signal was detected in eight biopsy specimens of normal skin from healthy donors. By Northern blot analysis, the expression of $\mathrm{HHV}-8$ was detected in 2 of $10 \mathrm{KS}$ tumors examined. Furthermore, the RNA transcripts were observed in endothelial cells lining the irregular vascular spaces and perivascular spindle-shaped cells histologically characteristic of KS in 2 out of 8 different KS specimens examined by in situ hybridization using an antisense probe specific for HHV-8. The detection of RNA expression of HHV-8 in KS tumors further supports the possible etiopathogenic role of this virus in the development of KS. ( $J$. Clin. Invest. 1996. 97:2803-2806.) Key words: Kaposi's sarcoma - HHV-8 - RNA transcription • in situ hybridization • AIDS
\end{abstract}

\section{Introduction}

A novel human herpesvirus-like agent $(\mathrm{HHV}-8)^{1}$ has recently been identified in the various forms of Kaposi's sarcoma (KS) including the HIV-negative "classical" (Mediterranean type) of KS (CKS), and endemic African (KS), AIDS-associated KS (AIDS-KS), and in a cohort of HIV-negative immunocompetent homosexual men with KS (1-4). The detection of HHV-8 in $\mathrm{KS}$ has been demonstrated by polymerase chain reaction (PCR) and confirmed in certain specimens by genomic South-

Address correspondence to Alvin E. Friedman-Kien, Departments of Dermatology and Microbiology, NYU Medical Center, 550 First Avenue, New York 10016. Phone: 212-263-5314; FAX: 212-263-7933.

Received for publication 15 December 1995 and accepted in revised form 22 February 1996.

1. Abbreviations used in this paper: KS, Kaposi's sarcoma; AIDS-KS, AIDS related-KS; CKS, classical Kaposi's sarcoma; HHV-8, human herpesvirus-like 8; RT-PCR, reverse transcription polymerase chain reaction.

J. Clin. Invest.

(C) The American Society for Clinical Investigation, Inc.

0021-9738/96/06/2803/04 \$2.00

Volume 97, Number 12, June 1996, 2803-2806 ern blot analysis and in situ hybridization (2-6). HHV-8 has also been detected in a few biopsy samples of "normal" appearing skin distant from any tumors from patients with KS (3-5). These findings suggest that HHV-8 may play a role in the pathogenesis of KS occurring among the disparate populations in which this tumor is seen.

If HHV-8 plays a role in the pathogenesis of KS, the expression and replication of this virus should be demonstrable in KS tissue. To clarify whether the HHV-8 DNA detected in $\mathrm{KS}$ tumors in fact, plays a role in the pathogenesis of this neoplasm, RNA expression of HHV-8 in fresh KS tumor biopsy specimens was examined by reverse transcription combined with PCR (RT-PCR), Northern blot, and in situ hybridization techniques.

\section{Methods}

Samples. 31 fresh KS skin biopsy specimens initially demonstrated to harbor HHV-8 DNA by PCR analysis were examined for the presence of HHV-8 RNA transcripts. Three of the KS tumor specimens were obtained from patients with CKS and 28 came from patients with AIDS-KS. A portion of each specimen was separately reserved for histopathological assessment. Eight samples of normal skin obtained from healthy patients undergoing plastic surgery were used as controls. Specimens were minced with a Tissue Mizer (Tekmar Co., Cincinnati, $\mathrm{OH}$ ), followed by acid guanidinum thiocyanate/phenol/ chloroform extraction of total RNA (7). $2 \mu \mathrm{g}$ of each RNA sample was incubated with $4 \mathrm{U}$ of ribonuclease-free deoxyribonuclease (Promega, Madison, WI) at $37^{\circ} \mathrm{C}$ for $30 \mathrm{~min}$ and then heated at $95^{\circ} \mathrm{C}$ for $5 \mathrm{~min}$ to inactivate the enzyme. One-third of each specimen was evaluated by PCR without the RT step in order to confirm that each RNA sample was free of DNA contamination (8). The remaining portion of each sample was incubated in $30 \mu \mathrm{l}$ of a solution containing $100 \mathrm{ng}$ random hexamer, $200 \mathrm{U}$ of the Moloney murine leukemia virus reverse transcriptase (GIBCO-BRL, Gaithersburg, Maryland), 50 $\mathrm{mM}$ Tris- $\mathrm{HCl}$ ( $\mathrm{pH} 8.3$ ), $75 \mathrm{MM} \mathrm{KCl}, 3 \mathrm{mM} \mathrm{MgCl}, 10 \mathrm{mM}$ DTT at $37^{\circ} \mathrm{C}$ for $1 \mathrm{~h}$. Each of the cDNA products were then equally divided into two aliquots for PCR amplification, one examined for HHV-8 and the other for $\beta$-actin to ascertain whether the DNA was amplifiable (9). The PCR solution contained $1 \mathrm{U}$ of Taq DNA polymerase, Taq buffer (Perkin-Elmer Corp., Norwalk, CT), a primer pair either for HHV-8 (5'-AGC, CGA, AAG, GAT, TCC, ACC, ATT-3', and 5'-TCC. GTG, TTG, TCT, ACG, TCC, AGA-3') or for $\beta$-actin (5'-GAG, GAG, CAC, CCC, GTG, CTG, CTG, A-3" and 5'-CTA, GAA, GCA, TTT, GCG, GTG, GAC, GAT, GGA, GGG, GCC-3'), and underwent 35 cycles of $1 \mathrm{~min}$ at $94^{\circ} \mathrm{C}, 1 \mathrm{~min}$ at $55^{\circ} \mathrm{C}$, and $1 \mathrm{~min}$ at $72^{\circ} \mathrm{C}(1,9)$. Upon completion of the amplification, the PCR products were analyzed by electrophoresis on a $1.5 \%$ agarose gel in Trisborate-EDTA buffer ( $\mathrm{pH}$ 8.0). Each of the DNA samples were then transferred to a Genescreen membrane (Dupont-NEN, Boston, MA). After prehybridization, the membranes were hybridized with a ${ }^{32} \mathrm{P}$-dATP end-labeled probe for either HHV-8 (5'-TTG, GAG, TAG, ATG, TGG, TAC, ACC, AAC, A-3') or $\beta$-actin (5'-GAA, ATC, GTG, CGT, GAC, ATT, AAG, GAG, AAG- $3^{\prime}$ ). The membranes were sequentially washed in $2 \times \mathrm{SSC}, 1 \times \mathrm{SSC}$, and $0.5 \times \mathrm{SSC}$ $\left(1 \times\right.$ SSC: $0.15 \mathrm{M}$ sodium chloride, $0.015 \mathrm{M}$ sodium citrate) at $55^{\circ} \mathrm{C}$ for 30 min each wash, and then autoradiographed with Kodak x-ray film (Eastman Kodak Co., Rochester, NY). 
Northern blot hybridization analysis. The RNAs extracted from $10 \mathrm{KS}$ samples and 2 specimens of normal skin were subjected to Northern blot hybridization analysis. $30 \mu \mathrm{g}$ of each RNA specimen was treated with formamide and formaldehyde, electrophoresed, and transferred to Genescreen membranes. A sequence-confirmed 233bp PCR-amplified HHV-8 DNA fragment which is a portion of the putative minor capsid gene was radiolabeled by random priming, and then added to the prehybridized membranes in the solution containing $1 \%$ SDS, $1 \mathrm{M}$ sodium chloride, $10 \%$ dextran sulfate, and salmon sperm DNA $(100 \mu \mathrm{g} / \mathrm{ml})$. After the membranes were sequentially washed in $2 \times \mathrm{SSC}, 1 \times \mathrm{SSC}$, and $0.2 \times \mathrm{SSC}$ at $60^{\circ} \mathrm{C}$, they were exposed to Kodak $\mathrm{x}$-ray film using an intensifying screen at $-70^{\circ} \mathrm{C}$ for autoradiographic analysis (10).

In situ hybridization. To make the HHV-8 probe, a 233-bp fragment of the PCR product was cloned into pSPT 18 vector (Boehringer Mannheim). ${ }^{33} \mathrm{P}-\mathrm{UTP}$-labeled single stranded RNA probes were prepared by transcribing the fragment with either T7 or SP6 RNA polymerase (Boehringer Mannheim). In situ hybridization was performed to detect RNA as described previously (11). Briefly, serial $5-\mu \mathrm{m}$ thick cryostat sections of eight AIDS-KS tissues and three control normal skin tissues were mounted on silane-coated glass microscope slides, fixed in $4 \%$ paraformaldehyde and dehydrated through graded ethanol. The dehydrated tissue sections were then acetylated in $0.1 \mathrm{M}$ trithanolamine, $0.25 \%$ acetic anhydride for $10 \mathrm{~min}$, washed in $0.2 \times \mathrm{SSC}$ and preincubated for $2 \mathrm{~h}$ at $45^{\circ} \mathrm{C}$ covered by a solution of

Table I. Detection of HHV-8 Transcription in Kaposi's Sarcoma

\begin{tabular}{|c|c|c|c|c|c|c|}
\hline Case & $\begin{array}{l}\text { Histologic } \\
\text { features }\end{array}$ & $\begin{array}{c}\text { HIV } \\
\text { serology }\end{array}$ & $\begin{array}{c}\text { PCR } \\
\text { HHV-8 }\end{array}$ & RT-PCR & $\begin{array}{l}\text { Northern } \\
\text { blot }\end{array}$ & $\begin{array}{c}\text { In Situ } \\
\text { hybridization }\end{array}$ \\
\hline $1 *$ & KS nodular & - & + & + & - & ND \\
\hline $2 *$ & KS plaque & - & + & + & ND & ND \\
\hline $3 *$ & KS patch/plaque & - & + & - & ND & ND \\
\hline 4 & $\mathrm{KS}$ patch/plaque & + & + & + & ND & ND \\
\hline 5 & KS patch/plaque & + & + & + & ND & ND \\
\hline 6 & $\mathrm{KS}$ patch/plaque & + & + & - & ND & ND \\
\hline 7 & KS plaque & + & + & + & - & ND \\
\hline 8 & KS plaque & + & + & + & + & + \\
\hline 9 & KS nodular & + & + & + & ND & - \\
\hline 10 & KS plaque & + & + & + & - & ND \\
\hline 11 & KS nodular & + & + & + & + & ND \\
\hline 12 & KS plaque & + & + & + & - & ND \\
\hline 13 & KS plaque & + & + & - & ND & - \\
\hline 14 & KS nodular & + & + & + & - & ND \\
\hline 15 & KS plaque & + & + & + & ND & + \\
\hline 16 & KS nodular & + & + & + & - & - \\
\hline 17 & KS plaque & + & + & + & ND & - \\
\hline 18 & KS nodular & + & + & + & - & - \\
\hline 19 & KS plaque & + & + & + & - & ND \\
\hline 20 & KS plaque & + & + & + & ND & - \\
\hline 21 & KS plaque & + & + & + & ND & ND \\
\hline 22 & KS plaque & + & + & + & ND & ND \\
\hline 23 & KS plaque & + & + & + & ND & ND \\
\hline 24 & KS plaque & + & + & + & ND & ND \\
\hline 25 & KS plaque & + & + & + & ND & ND \\
\hline 26 & KS plaque & + & + & + & ND & ND \\
\hline 27 & KS nodular & + & + & + & ND & ND \\
\hline 28 & KS nodular & + & + & + & ND & ND \\
\hline 29 & KS plaque & + & + & + & ND & ND \\
\hline
\end{tabular}

*CKS; $(+)$ positive; (ND) not done; $(-)$ negative.

\section{A $\quad 1234567891011+2131415161718$}

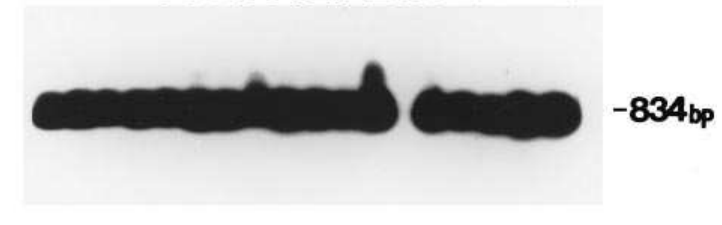

B $\quad 123456789101112131415161718$
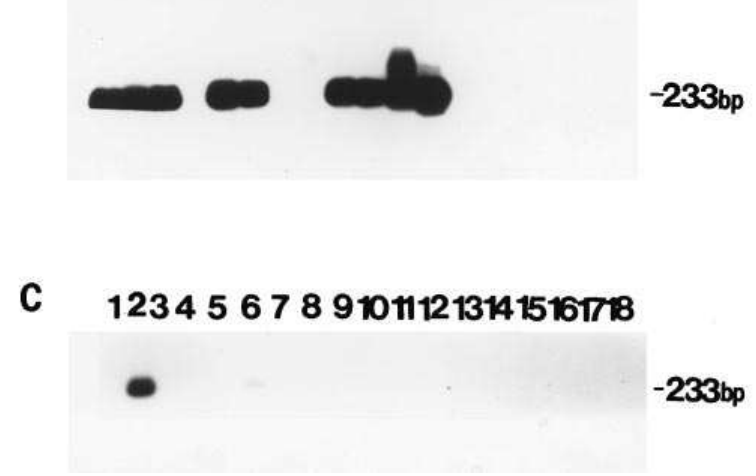

Figure 1. Representative result of the detection of HHV-8 transcription in KS tumors by RT-PCR. Southern blot hybridization was performed on amplified products for $\beta$-actin RNA $(A)$, HHV-8 RNA $(B)$, and HHV-8 DNA $(C)$. Lanes 1-12, RNA extracted from KS tumors; lanes 13-18, samples of normal skin. An amplified 834-bp band is not observed in lane 13 of $A$ which indicates that RNA from this sample is not amplifiable. An amplified 233-bp band is observed in lane 2 and 6 of $C$ which indicates that residual DNA exists in these two samples of RNA. Therefore, KS samples in lanes 1, 3, 5, and 9-12 are positive, in lanes 4,7 , and 8 are negative, and in lane 2 and 6 are interpreted as false positive. Specimens of normal skin in lanes 14 to 18 are negative.

$50 \%$ formamide, $0.6 \mathrm{M} \mathrm{NaCl}, 2.5 \times$ Denhardt's solution, $10 \%$ dextran sulfate, $10 \mathrm{mM}$ Tris- $\mathrm{HCl}$ (pH 7.5), $1 \mathrm{mM}$ EDTA, $0.1 \%$ SDS and 0.15 $\mathrm{mg} / \mathrm{ml} \mathrm{t}$-RNA. The tissue sections were then incubated with ${ }^{33} \mathrm{P}$ labeled anti-sense probe in the same solution at $45^{\circ} \mathrm{C}$ for $16 \mathrm{~h}$. The slides were washed in $2 \times \mathrm{SSC}$, treated with RNAse $(5 \mu \mathrm{g} / \mathrm{ml})$, sequentially washed for $30 \mathrm{~min}$ each in $1 \times \mathrm{SSC}, 0.5 \times \mathrm{SSC}$ at $60^{\circ} \mathrm{C}$, dehydrated, and finally coated with Kodak NTB-2 emulsion. After 7-14 d, the slides were developed and counterstained with hematoxylin. A ${ }^{33}$ P-labeled sense probe was used as a control.

\section{Results}

31 KS specimens shown to contain HHV-8 DNA by PCR were further examined for the presence of viral RNA transcripts using RT-PCR. The results are summarized in Table I with representative examples of the amplification products shown in Fig. 1. To ensure that the RNA extracted from each specimen was amplifiable, RT-PCR was also performed with a primer pair specific for $\beta$-actin. A 834-bp amplified band was detected in all RNA specimens with the exception of one sample extracted from a normal skin specimen (Fig. $1 A$ ). Direct PCR was also performed on all RNAse-free DNAse treated RNA samples to determine whether any residual HHV-8 template DNA was present. The amplified 233 bp fragment was detected in two of the AIDS-KS specimens (Fig. 1 C); therefore, positive results from the corresponding RT-PCR of these two samples were not counted. The positive results of RT-PCR 


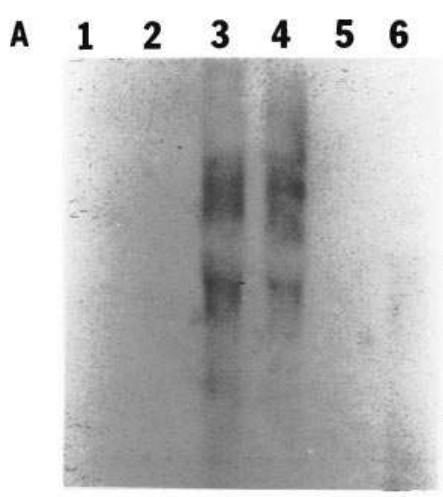

$-28 S$

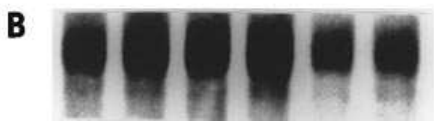

Figure 2. Northern blot analysis for detection of the expression of HHV-8 in KS tumors. $(A) \mathrm{Ex}-$ amination of HHV-8 transcription by ${ }^{32} \mathrm{P}$ dCTP end-labeled probe specific for HHV-8. Positive bands were detected in two KS tumor samples (lanes 3 and 4). (B) Membrane probed with $\beta$-actin. Lanes 1-5, RNA samples extracted from AIDS-KS lesions. Lane 6, RNA obtained from normal skin. amplified originally from viral RNA were identified in 26 of 29 $\mathrm{KS}$ specimens examined, including 2 of $3 \mathrm{CKS}$ and 24 of $26 \mathrm{KS}$ specimens from AIDS patients. No positive signals were elicited from the normal control skin specimens (Fig. 1, $B$ and $C$ ).

To further confirm the expression of HHV-8 RNA in KS tumors, the available RNAs from nine AIDS-KS lesions and one non-HIV-related CKS specimen were analyzed by North- ern blot hybridization. The HHV-8 RNA transcripts were found in two specimens from AIDS-KS patients (Fig. 2). No positive signals were observed by Northern blot in the remaining eight KS samples (1 CKS, 7 AIDS-KS), although HHV-8 RNA transcripts had been previously detected by RT-PCR in all of these specimens. In the two control samples of skin, HHV-8 RNA expression was not detected by Northern blot analysis.

To attempt to localize the expression of HHV-8 RNA to specific cells within KS tumor tissues, in situ hybridization was performed on $5-\mu \mathrm{m}$ frozen sections of KS specimens. In 2 of 8 AIDS-KS samples examined, HHV-8 RNA transcripts were detected and localized to the endothelial cells lining the irregular vascular slits and to perivascular spindle-shaped cells histologically characteristic of KS (Fig. 3). The specific detection of HHV-8 RNA in these cells by in situ hybridization was further established by using a sense probe on the same tissue sections; no positive signal was detected in the controls (12).

\section{Discussion}

Using PCR and in situ hybridization we have recently demonstrated the presence of HHV-8 in the endothelial cells and perivascular spindle cells typically seen in KS tissue specimens suggesting that this herpesvirus may be involved in the pathogenesis of KS (6). However, HHV-8 DNA has also been de-
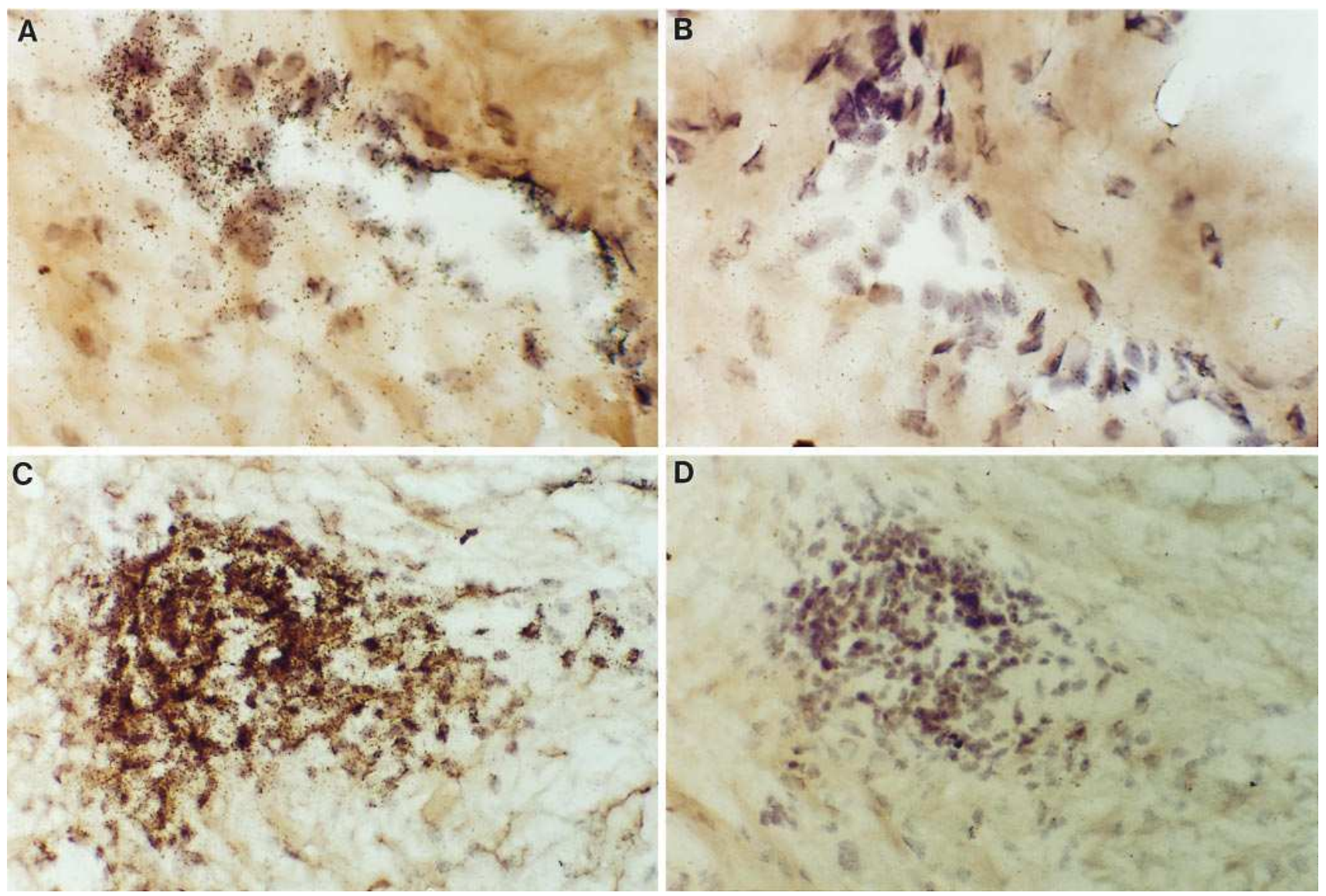

Figure 3. In situ hybridization with HHV-8 specific probe for detection of HHV-8 transcripts in AIDS-KS tumors. (A) Localization of HHV-8 RNA (silver grains) to the nuclei of vascular endothelial cells and perivascular spindle-shaped cells of a KS tumor $(\times 200)$. $(B)$ Negative control using sense RNA probe on the same specimen; only background levels of grains are present. (C) Strong labeling of the vascular endothelial cells and perivascular spindle-shaped cells in another KS lesion is observed $(\times 125)$. $(D)$ No labeling is seen after hybridization with a sense RNA probe $(\times 125)$. 
tected in normal appearing skin from patients with KS distant from any KS lesions, as well as in some AIDS-associated body cavity lymphomas BCBL. Recently, lytic growth of HHV-8 has been observed in cells derived from an AIDS-related BCBL-based (14). To date, the virus has not been observed by electron microscopy in either KS tumors or KS-derived cultured cells. The present study was designed to ascertain whether HHV-8 is expressed in KS tumors and to determine in which cells of the tumor HHV-8 transcripts are localized.

Using the RT-PCR techniques, RNA expression of HHV-8 was detected in $89.7 \%(26 / 29)$ of KS specimens examined. The transcription of HHV-8 was not detected in $3 \mathrm{KS}$ samples which were only positive for HHV-8 by PCR. There are several possible explanations for this observation; the detection of mRNA by the RT-PCR method has technical limitations (15). The absence of RNA detection in some of the specimens could be related to insufficient or very low levels of transcription. Alternatively, despite the precautions taken, RNA degradation due to instability may have yielded negative results, especially in the circumstance of low level RNA expression, or some of the KS specimens may harbor HHV-8 in the absence of viral expression. The expression of HHV-8 in some of the fresh KS specimens examined was further confirmed by Northern blot hybridization analysis.

The histopathological features of KS include a proliferation of spindle-shaped cells forming fascicles or bundles that surround and eventually compress the irregular vascular spaces lined with endothelial cells, and an inflammatory cell infiltrate composed of plasma cells, lymphocytes, and monocytes; dermal dendrocytes and extravasated erythrocytes, are also present. Although the progenitor cell of KS remains undetermined, vascular or lymphatic endothelial cells, dermal dendrocytes, and vascular smooth muscle cells have been proposed to be the cell of origin of KS (16). The present study demonstrates by in situ hybridization that the RNA expression of HHV-8 is localized to the endothelial cells that line the bizarre-shaped vascular structures and to some of the perivascular spindle-shaped cells seen in KS lesions. These observations are consistent with, and confirm, our recent in situ hybridization studies which demonstrate that HHV-8 DNA is localized to the vascular endothelial cells and perivascular spindleshaped cells in KS tissues (6).

RNA expression of HHV-8 in KS tumors was detected by three different techniques. Our data show that the positive ratio of HHV-8 transcripts detected by RT-PCR is much higher than that detected by Northern blot or in situ hybridization. These results could be explained by the high sensitivity of the RT-PCR method; the present study indicated that the level of RNA expression of HHV-8 is not high enough in all KS tumor samples for detection by less sensitive methods such as Northern blot and in situ hybridization. Therefore, the relationship between the level of expression of HHV-8 and the stages of KS development needs to be further studied by establishing a quantitative RT-PCR method. Nevertheless, the detection of RNA expression of HHV-8 in a high percentage of KS tumors reported here suggests that HHV-8 may play a role in the pathogenesis of KS.

\section{Acknowledgments}

This work was supported by a grant from the Howard Gilman Foundation and by National Institutes of Health grant CA-62782 and CA70075-02.

\section{References}

1. Chang, Y., E.C. Cesarman, M.S. Pessin, F. Lee, J.C. Culpepper, D.M. Knowles, and P.S. Moore. 1994. Identification of herpesvirus-like DNA sequences in AIDS-associated Kaposi's sarcoma. Science (Wash. DC). 266:18651869.

2. Huang, Y.Q., J.J. Li, M. Kaplan, B.J. Poiesz, W.C. Zhang, D. Feiner, E. Katabira, and A.E. Friedman-Kien. 1995. Prevalence of human herpes viruslike nucleic acid in various forms of Kaposi's sarcoma. Lancet. 345:759-761.

3. Ambroziak, J.A., D.J. Blackburn, B.G. Herndier, R.G. Glogau, J.H. Gullett, A.R. McDonald, E.T. Lennette, and J.A. Levy. 1995. Herpes-like sequences in HIV-infected and uninfected Kaposi's sarcoma patients. Science (Wash. DC). 268:582-583.

4. Moore, P.S., and Y. Chang. 1995. Detection of herpesvirus-like DNA sequences in Kaposi's sarcoma in patients with those without HIV infection. $N$. Engl. J. Med. 332:1181-1185.

5. Huang, Y.Q., J.J. Li, B.J. Poiesz, M.H. Kaplan, and A.E. Friedman-Kien. 1995. Occurrence of the human $\gamma$ herpesvirus-like agent (HHV-8) in matched specimens of semen, blood, epidemic Kaposi's sarcoma (EKS) lesions and uninvolved skin from patients with and without HIV infection. Submitted for publication.

6. Li, J.J., Y.Q. Huang, C.J. Cockerell, and A.E. Friedman-Kien. 1996. Detection of the herpesvirus-like agent (HHV-8) in classic and epidemic Kaposi's sarcoma by in situ hybridization. Am. J. Pathol. 148(6):1641-1648.

7. Chromczyrski, P., and H. Sacchi. 1987. Single-step method of RNA isolation by acid guaridinum thiolyanate-phenol-chloroform extraction. Anal. Biochem. 162:156-159.

8. Joske, D.J., A.E. Goodman, E. Bachmann, F. Bachmann, B. Odermatt, and H. Knecht. 1992. Epstein-Barr virus burden in Hodgkin's disease is related to latent membrane protein gene expression, but not to active viral replication. Blood. 80:2610-2613.

9. Huang, Y.Q., J.J. Li, S.W. Kim, A. Nicolaides, W.G. Zhang, J. Le, B.J. Poiesz, and A.E. Friedman-Kien. 1993. HIV-1 infection and modulation of expression of cytokines and growth factors in Kaposi's sarcoma-derived cell cultures. AIDS. 7:317-322.

10. Huang, Y.Q., B. Raphael, A. Buchbinder, J.J. Li, W.G. Zhang, and A.E. Friedman-Kien. 1994. Rearrangement and expression of $\mathrm{MDM}_{2}$ oncogene in chronic lymphocytic leukemia. Am. J. Hematol. 47:139-141.

11. Li, J.J., Y.Q. Huang, B.J. Poiesz, and A.E. Friedman-Kien. 1992. Detection of HIV-1 in urine pellets of HIV-1 seropositive individuals. J. Clin. Microbiol. 30:1051-1055.

12. Shibata, D., and L.M. Weiss. 1992. Epstein-Barr virus-associated gastric adenocarcinoma. Am. J. Path. 140:769-774.

13. Deleted in proof.

14. Renne, R., W. Zhang, B. Herndier, M. McGrath, N. Abbey, and D. Ganem. 1996. Lytic growth of Kaposi's sarcoma-associated herpes virus (human herpesvirus 8) in culture. Nature Med. 2:342-346.

15. Gozlan, J., J.M. Salord, C. Christos, C. Duvivier, O. DiCarol, M.C. Meyohas, and J.C. Petit. 1993. Human cytomegalovirus (HCMV) late-mRNA detection in peripheral blood of AIDS patients: diagnostic value for HCMV disease compared with those of viral culture and HCMV DNA detection. J. Clin. Microbiol. 31:1943-1945.

16. Roth, W.K., H. Brandstetter, and M. Stürzl. 1992. Cellular and molecular features of HIV-associates Kaposi's sarcoma. AIDS. 6:895-913. 